\title{
Determination of Essential and Non-essential Metals Concentration in Garlic (Allium sativum L.) Bulb and Leaf Cultivated in Ambo Woreda, Ethiopia
}

\author{
Wodaje Addis Tegegne, Alemayehu Abebaw Mengiste \\ Department of Chemistry, College of Natural and Computational Science, Ambo University, Ambo, Ethiopia \\ Email address: \\ wedajeaddis@yahoo.com (W. A. Tegegne), alemayehuabebaw@yahoo.com (A. A. Mengiste) \\ To cite this article: \\ Wodaje Addis Tegegne, Alemayehu Abebaw Mengiste. Determination of Essential and Non-essential Metals Concentration in Garlic (Allium \\ sativum L.) Bulb and Leaf Cultivated in Ambo Woreda, Ethiopia. Science Journal of Analytical Chemistry. Vol. 4, No. 6, 2016 , pp. 84-94. \\ doi: $10.11648 /$ j.sjac.20160406.12
}

Received: May 23, 2016; Accepted: June 2, 2016; Published: January 3, 2017

\begin{abstract}
In this study, the levels of twelve essential metals ( $\mathrm{Na}, \mathrm{K}, \mathrm{Ca}, \mathrm{Mg}, \mathrm{Fe}, \mathrm{Zn}, \mathrm{Mn}, \mathrm{Cu}, \mathrm{Mo}, \mathrm{Co}, \mathrm{Cr}$ and $\mathrm{Ni}$ ) and two non-essential metals $(\mathrm{Pb}$ and $\mathrm{Cd}$ ) were determined in the bulb and leafs of garlic (Allium sativum $\mathrm{L}$.) cultivated in Ambo Woreda, Ethiopia. Wet digestion method using a mixture of $5 \mathrm{ml}$ of concentrated $\mathrm{HNO}_{3}: \mathrm{HClO}_{4}(4: 1 \mathrm{v} / \mathrm{v})$ was used for digestion of the samples. The determination processes were done by flame photometer for $\mathrm{Na}$ and $\mathrm{K}$, EDTA titration method for $\mathrm{Ca}$ and $\mathrm{Mg}$, and ICP-OES for the rest of the metals. The results obtained revealed that the concentrations of metals in the garlic bulb samples in $\mathrm{mg} / \mathrm{kg}$ dry weight were in the range of: $\mathrm{Na}$ (217-366.7), $\mathrm{K}$ (9080-12060), Ca (1018-1286), Mg (802-992.6), Fe (63.44-91.24), Zn (31.17-35.39), Mn (5.27-7.51), Cu (4.21-7.16), Mo (1.06-2.08), Co (0.61-1.49), Ni (1.45-3.78), Cr (0.47$1.31), \mathrm{Pb}(1.07-2.51)$ and $\mathrm{Cd}(0.10-0.16)$. The concentrations of metals in the garlic leaf samples in $\mathrm{mg} / \mathrm{kg}$ dry weight were in the range of: $\mathrm{Na}$ (463-730), K (11370-12860), Ca (1209-1302), Mg (871-994), Fe (72.3-108), Zn (49.1-71.39), Mn (26.7472.36), Cu (5.41-8.44), Mo (1.01-2.30), Co (1.17-4.96), Ni (2.17-3.54), Cr (1.20-2.17), Pb (1.87-2.84) and Cd (0.12-0.18). In addition, the results show that the levels of elements were higher in the leaves than the bulbs. In general, the levels of metals in the analyzed garlic bulb and leaf samples were found below the FAO/WHO maximum permissible limit; hence they are safe for human consumption and can be considered as a good source of essential nutrients.
\end{abstract}

Keywords: Essential Metals, Non-essential Metals, Garlic (Allium sativum L.), Wet Digestion, ICP-OES

\section{Introduction}

Garlic (Allium sativum L.), the second most important Allium crop next to the onion (Allium cepa L.), is cultivated worldwide and consumed by almost every culture as a popular condiment and green vegetable [1]. Garlic has been used throughout its history for both culinary and medicinal purposes [2]. Garlic (Allium sativum L.) is the most widely used bulb vegetable next to onion in Ethiopia. It contributes significant nutritional value to the human diet [3]. Garlic (Allium sativum L.) has a long folklore history as a treatment for cold, cough, asthma and is reported to strengthen the immune system. It has many medicinal effects such as lowering of blood cholesterol level, antiplatelet aggregation, antihelmantic, anti-inflammatory activity and inhibition of cholesterol synthesis. Garlic has long been known to have antibacterial, antifungal, anticancer and antiviral properties $[4,5]$.

Pollution of foods by heavy metals is a worldwide phenomenon. Studies have revealed that fruits and leafy vegetables are vulnerable to heavy metal contamination from soil, wastewater and air pollution. The toxicity and consequent threat to human health by heavy metals such as cadmium, copper, lead, chromium, zinc, nickel, cobalt, arsenic and mercury are a function of concentration and bioaccumulation [6, 7]. The implications associated with metal contamination are of great concern, particularly in agricultural production systems due to their increasing trends in human foods and environment [8]. They are ubiquitous in the environment through various pathways, due to natural and anthropogenic activities [9]. Source of anthropogenic contamination include the addition of manures, sewage 
sludge, fertilizers and pesticides to soils, several studies identifying the risks in relation to increased soil metal concentration and consequent plant uptake [10].

Heavy metals are non-biodegradable and bioaccumulate in living tissues through the food chain. This fact necessitates for frequent determination of heavy metals in vegetables and soil for the safety of consumers. Fruits, vegetables and other foods are among pathways by which heavy metals enter the human tissues leading to deterioration of health [7]. Excessive amount of heavy metals in food cause a number of diseases, especially cardiovascular, renal, neurological, and bone diseases $[10,11]$.

Elements such as nickel, zinc, iron, copper and magnesium etc. are essential because they are associated with enzyme systems and other biochemical processes in the body. In spite of their benefits, some trace elements cannot be regarded as essential to life. Lead, cadmium, arsenic, and mercury are toxic at very low concentrations and are termed nonessential. Cadmium and lead in any concentrated can caused kidney damage and toxicity symptoms include impaired kidney function, poor reproductive capacity, hypertension, tumors, etc. [12]. However, whether essential or not, when bioaccumulated, once they exceed the total body burden, disease conditions may arise [13].

Minerals are nutritionally important components in food, they are necessary for health, and are part of all aspect of cellular function. They are involved in structural components and also form an integral part of enzyme or protein structure. Minerals are essential for growth, development and maintenance of tissues and are also linked to the expression of genetic information, the effectiveness of immune system, the prevention of cell damage. In general, minerals increase resistance to many chronic and some infectious diseases [14].

However, studies are mainly focused on the medicinal values of garlic; the study which was conducted on the nutritional values of garlic is scarce. Before the commencement of this work, there are no literature reports on the content of essential and non-essential metals in Allium sativum L. (garlic) cultivated in Ambo Woreda. So the main objective of this study was to determine the levels of essential metals (Na, K, Ca, Mg, Fe, Zn, Mn, Cu, Mo, Co, Ni and $\mathrm{Cr}$ ) and non-essential metals $(\mathrm{Pb}$ and $\mathrm{Cd})$ in garlic bulb and leaf samples and their comparative distribution in different locations of Ambo Woreda, West Shoa Zone of Oromia Regional State, Ethiopia for $\mathrm{Na}$ and $\mathrm{K}$ using flame photometer, $\mathrm{Ca}$ and $\mathrm{Mg}$ by EDTA titration method, and the rest of the metals using inductively coupled plasma-optical emission spectrometry.

\section{Materials and Methods}

\subsection{Study Area}

The study was conducted in 4 locations of Ambo Woreda (Awaro Qora, Gosu Qora, Qibafkube and Elamu Goromti) Kebeles in West Shoa Zone of Oromia Region which is about $112 \mathrm{~km}$ West of Addis Ababa, the capital city of Ethiopia. Ambo is located between latitude $8^{\circ} 59^{\prime} \mathrm{N}$ and longitude $37^{\circ} 51^{\prime} \mathrm{E}$ with an elevation of 2101 meters above sea level, The temperature ranges from $15^{\circ} \mathrm{C}-29^{\circ} \mathrm{C}$ with average temperature of $22^{\circ} \mathrm{C}$ (Figure 1).

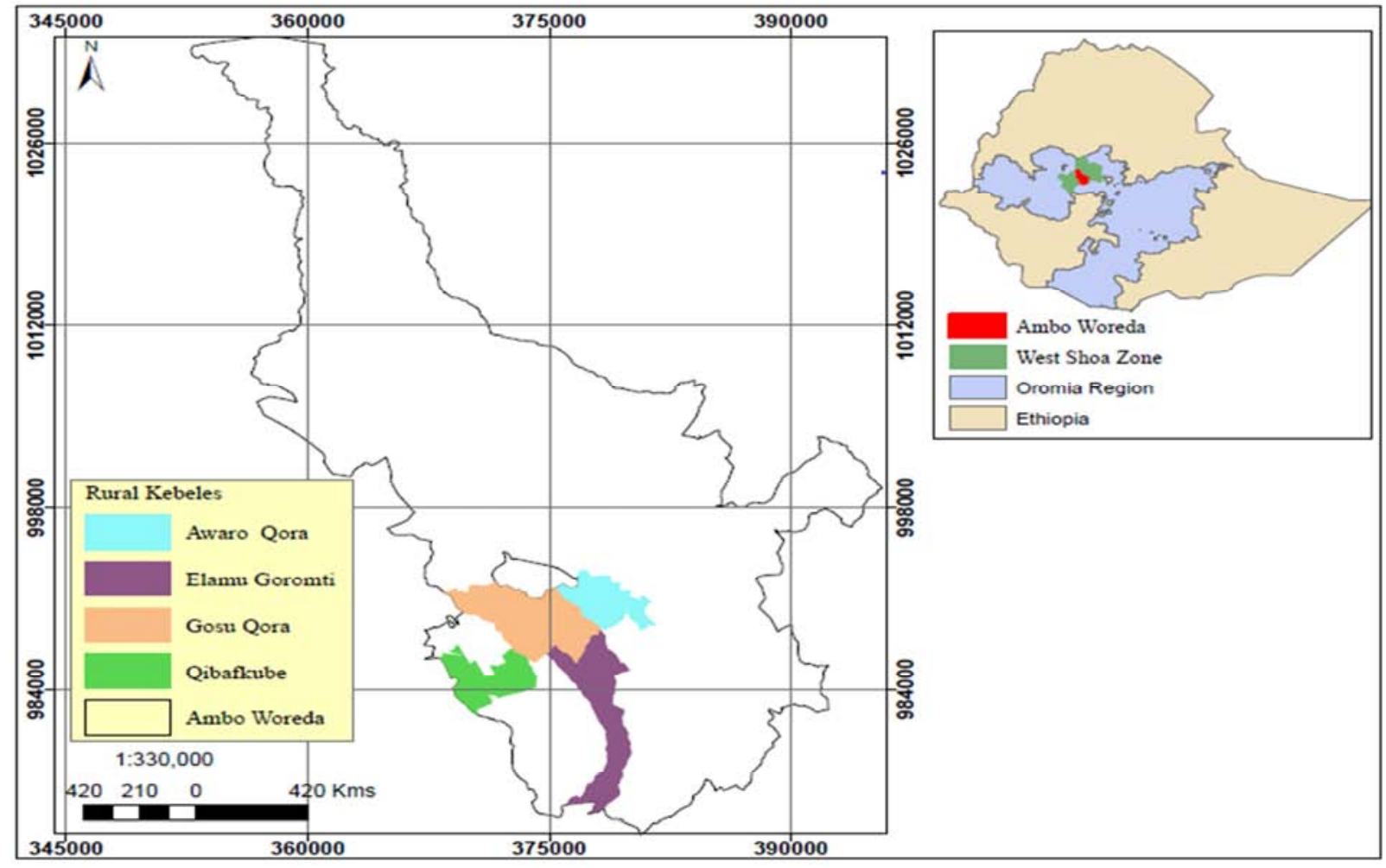

Figure 1. Map of the study area. 


\subsection{Chemicals and Reagents}

All the chemicals used for this work were of analytical grades obtained from Uni-Chem ${ }^{\circledR}$ India. $65-68 \%$ nitric acid $\left(\mathrm{HNO}_{3}\right)$ and $70-72 \%$ perchloric acid $\left(\mathrm{HClO}_{4}\right)$ were used for sample digestion. $1000 \mathrm{mg} / \mathrm{L}$ of stock standard solution of each of the metals to be determined were used for the preparation of spiking and calibration standards. Double distilled water was used throughout the work.

\subsection{Instrument and Apparatuses}

Inductively coupled plasma-optical emission spectrometry (ICP-OES) model Agilent 720 was used for the determination of $\mathrm{Fe}, \mathrm{Zn}, \mathrm{Mn}, \mathrm{Cu}, \mathrm{Mo}, \mathrm{Co}, \mathrm{Ni}, \mathrm{Cr}, \mathrm{Pb}$ and $\mathrm{Cd}$. Flame photometry model ELICO CL-378 was used for the determination of $\mathrm{Na}$ and $\mathrm{K}$, while $\mathrm{Ca}$ and $\mathrm{Mg}$ were determined by EDTA titration method. Drying oven (Model DHG-9070A, Shanghai, China) was used for drying the garlic bulb and leaf samples. An analytical balance with an accuracy of $\pm 0.0001 \mathrm{~g}$ (Model AA-200DS, Deriver Instrument Company, Germany) was used for weighing the samples. Digestive Furnace (Model: KDN-20C China) was used for sample digestion. All flasks and glassware were washed with tap water using detergent, immersed in $10 \%$ (v/v) $\mathrm{HNO}_{3}$ solution for 24 hours, and rinsed thoroughly with double distilled water.

\subsection{Sample Collection}

The garlic samples were collected in February, 2015 from the four agricultural Kebeles of Ambo Woreda (Awaro Qora, Gosu Qora, Qibafkube and Elamu Goromti). From each sample site, garlic samples were collected from five different sub-sites (farm lands) to provide replicate samples of each site. These farmlands were chosen randomly. Five fresh garlic samples were collected from centers and corners of each sub-farm land. The five sub-samples were mixed together to form a composite sample that represent each sampling areas. Finally, four garlic bulk samples one from each stated areas were collected and put in clean plastic bags labeled and brought into the laboratory for further treatment.

\subsection{Sample Treatment}

The bulb and leaf parts of the garlic were separated with stainless steel Teflon knifes, the bulbs were peeled and rinsed with tap water and then with distilled water to eliminate adsorbed dust particles. All the samples were cut into small sizes to facilitate drying of the pieces at the same rate and subsequently dried in the drying oven at $80^{\circ} \mathrm{C}$ for 48 hours to constant weight. The dried samples were ground into powder using mortar and pestle and then passed through a $0.5 \mathrm{~mm}$ mesh sieve. The samples were kept in plastic containers prior to analysis.

\subsection{Preparation of Samples}

$0.5 \mathrm{~g}$ of each garlic bulb and leaf samples were taken in to a digestive tubes containing a mixture of $5 \mathrm{ml}$ of concentrated $\mathrm{HNO}_{3}: \mathrm{HClO}_{4}(4: 1 \mathrm{v} / \mathrm{v})$. The mixture was digested in a digestive furnace (Model: $\mathrm{KDN}-20 \mathrm{C}$, China) by setting the temperature first $150^{\circ} \mathrm{C}$ for the first 1 hour, then increasing to $175^{\circ} \mathrm{C}$ for the remaining 2 hours. The digest was allowed to cool for 10 minutes without dismantling the condenser and further 10 minutes after removing the condenser. The digest was then diluted with $10 \mathrm{ml}$ double distilled water and filtered through Whatman filter paper No. $41 \mathrm{in}$ to $50 \mathrm{ml}$ volumetric flask. The digestive flask further rinsed with $10 \mathrm{ml}$ double distilled water and added to the filtrate, and the flask containing the filtrate was made up to the mark with double distilled water. Each sample was digested in triplicate and transferred into clean and dry plastic bottles, labeled and stored in refrigerator at $4{ }^{\circ} \mathrm{C}$ until analysis by ICP-OES. The blank solutions were undergoing the same digestion procedure as that of the samples.

\subsection{Preparation of Calibration Standards and Spiking Standards}

For calibration of the instruments, a series of five standard solutions were prepared by appropriate dilutions from 1000 ppm stock standard solution of the metals to be analyzed into $100 \mathrm{ml}$ volumetric flasks. The prepared metal concentrations include: $0.2,0.5,1,1.5$ and $2 \mathrm{ppm}$ of $\mathrm{Fe}, \mathrm{Zn}, \mathrm{Mn}, \mathrm{Cu}, \mathrm{Mo}$, $\mathrm{Co}, \mathrm{Ni}, \mathrm{Cr}, \mathrm{Pb}$ and $\mathrm{Cd}$, and 1, 2, 4, 8, 16 ppm of $\mathrm{Na}$ and $\mathrm{K}$.

For the spiking processes, a mixture of standard solution containing $4 \mathrm{mg} / \mathrm{L}$ of each $\mathrm{Na}$ and $\mathrm{K} ; 1 \mathrm{mg} / \mathrm{L}$ of $\mathrm{Fe}, \mathrm{Zn}, \mathrm{Mn}$, $\mathrm{Cu}, \mathrm{Mo}, \mathrm{Co}, \mathrm{Ni}, \mathrm{Cr}, \mathrm{Pb}$ and $\mathrm{Cd}$ was prepared by serial dilution from $1000 \mathrm{mg} / \mathrm{L}$ stock standard solution in to $100 \mathrm{ml}$ volumetric flask and diluting to the mark with double distilled water.

\subsection{Method Validation}

The proposed method was validated by evaluating different parameters such as linearity, matrix effect, limit of detection (LOD), limit of quantitation (LOQ), accuracy (in terms of recovery) and precision (in terms of repeatability) [15].

\subsubsection{Accuracy and Precision}

The accuracy and precision of the proposed procedure were evaluated by the analysis of matrix spike samples and laboratory control samples. Accuracy was evaluated through recovery studies of sample spikes. Precision was evaluated regarding repeatability by estimating the relative standard deviation (RSD) of the recovery percentage for each spiked level.

In this study, the recovery test was done by spiking a suitable known quantity of metal standard solution into a test portion of the sample. For doing so, each sample was spiked in triplicates at near mid-range calibration concentration (4.0 $\mathrm{mg} / \mathrm{L}$ of each of $\mathrm{Na}$ and $\mathrm{K} ; 1.0 \mathrm{mg} / \mathrm{L}$ of $\mathrm{Ca}, \mathrm{Mg}, \mathrm{Fe}, \mathrm{Zn}, \mathrm{Mn}$, $\mathrm{Cu}, \mathrm{Mo}, \mathrm{Co}, \mathrm{Ni}, \mathrm{Cr}, \mathrm{Pb}$ and $\mathrm{Cd}$ ). The spiked and non-spiked samples were digested and analyzed using the same analytical procedure as the garlic sample. The percent 
recoveries of the analyte were calculated by using equation 1 $[16,17]$.

$$
\% \text { Recovery }=\frac{\text { spiked result }- \text { unspiked result }}{\text { added amount }} \times 100
$$

Where, conc. $=$ concentration of metal of interest.

The relative standard deviation for replicate analyses of the same sample was obtained as dividing the standard deviation by the mean value of the analytical data according to the following equation [16].

$$
\% \operatorname{RSD}=\frac{s}{\overline{\mathrm{X}}}
$$

Where, $S=$ standard deviation and $\bar{X}$ the mean of the replicate analysis.

\subsubsection{Limit of Detection}

The limit of detection (LOD) is taken as the lowest concentration of an analyte in a sample that can be detected, but not necessarily quantified, under the stated conditions of the test. LOD is calculated as:

$$
\mathrm{LOD}=3 \mathrm{~S}_{\mathrm{a}} / \mathrm{b}
$$

Where $\mathrm{S}_{\mathrm{a}}$ is the standard deviation of the response; can be obtained by standard deviation of blank, response residual standard deviation of the regression line, or standard deviation of the y-intercept of the regression line and $b$ is the slope of the calibration curve [18, 19]. In this study, the LOD was obtained from triplicate analysis of reagents blanks which were digested in the same digestion procedure as the actual samples. The LOD for each analyte was calculated and the results are presented in Table 1.

\subsubsection{Limit of Quantitation}

The limit of quantitation (LOQ) is the lowest concentration of an analyte in a sample that can be quantitatively determined with acceptable precision and accuracy under the stated conditions of test $[18,19]$. LOQ is calculated as:

$$
\mathrm{LOQ}=10 \mathrm{~S}_{\mathrm{a}} / \mathrm{b}
$$

Where $\mathrm{S}_{\mathrm{a}}$ is the standard deviation of the response and $\mathrm{b}$ is the slope of the calibration curve [18]. In this study, LOQ was obtained from triplicate analysis of reagents blanks which were digested in the same digestion procedure as the actual samples. The LOQ for each analyte was calculated and the results are indicated in Table 1.

\subsubsection{Contamination Control}

Many measurement processes are prone to contamination, which can occur at any point in the sampling, sample preparation, instrument or analysis [20]. Therefore, to control this contamination effects the following controlling mechanisms are performed.

Calibration Blank: To measure the amount of the analytical signal that arises from the solvents and reagents; a calibration blank of $2 \% \mathrm{HNO}_{3}$ was prepared and run together with the standards for creating zero concentration point of the calibration graph. This helps to establish the baseline of an instrument.

Method Blank: Method blank is an analyte-free sample carried through the analysis using the same reagents, glassware and instrumentation. Method blanks are used to identify and correct systematic errors due to impurities in the reagents, contamination in the glassware and instrumentation [21].

In this study, $0.5 \mathrm{~g}$ sucrose was used as matrix for the garlic bulb and leaf samples. The blanks which were prepared from sucrose were treated exactly like the sample including exposure to all glassware, digestion media, apparatus, solvents and reagents that are used with other samples but with no added sample.

Laboratory Control Sample: The laboratory control sample (LCS) was analyzed in an identical manner as a sample and the results were used to assess accuracy and precision of the analytical methodology. Results within $\pm 10 \%$ of the true value are accepted. In this work, $0.5 \mathrm{~g}$ sucrose were spiked with $4.0 \mathrm{mg} / \mathrm{L}$ of each of $\mathrm{Na}$ and $\mathrm{K} ; 1.0 \mathrm{mg} / \mathrm{L}$ of $\mathrm{Ca}, \mathrm{Mg}, \mathrm{Fe}, \mathrm{Zn}, \mathrm{Mn}, \mathrm{Cu}, \mathrm{Mo}, \mathrm{Co}, \mathrm{Ni}, \mathrm{Cr}, \mathrm{Pb}$ and $\mathrm{Cd}$. The spiked samples were digested like the garlic samples including exposure to all glassware, digestion media, apparatus, solvents and reagents that are used with the garlic samples. The percent LCS recoveries for each metal were calculated using the following equation [22].

$$
\% \mathrm{R}=\frac{\mathrm{LCS}-\mathrm{MB}}{\mathrm{S}} \times 100
$$

Where: $\% \mathrm{R}=$ percent recovery, $\mathrm{LCS}=$ Laboratory Control Sample Results, $\mathrm{S}=$ amount of spike added and $\mathrm{MB}=$ results of the method blank

\subsection{Elemental Analyses of Samples}

The digested garlic bulb and leaf samples were analyzed for $\mathrm{Ca}$ and $\mathrm{Mg}$ by EDTA titration method; $\mathrm{Na}$ and $\mathrm{K}$ using flame photometer (Model: ELICO CL-378) and Fe, Zn, Mn, $\mathrm{Cu}, \mathrm{Mo}, \mathrm{Co}, \mathrm{Ni}, \mathrm{Cr}, \mathrm{Pb}$ and $\mathrm{Cd}$ using Agilent 720 Inductively Coupled Plasma Optical Emission Spectrometry (ICP-OES) after calibrating the instruments using calibration blank and five series of working standard solutions of each metal to be analyzed. Final concentration of element in the samples was calculated as:

$$
\text { Concentration }(\mathrm{mg} / \mathrm{kg})=\frac{\text { Concentration }(\mathrm{mg} / \mathrm{L}) \times \mathrm{V}}{\mathrm{W}}
$$

Where: $\mathrm{V}$ is the final volume of the digested solution $(50 \mathrm{ml})$ and $\mathrm{W}$ is the weight of the sample $(0.5 \mathrm{~g})$.

\subsection{Statistical Analysis}

All analyses were carried out in triplicates and the data were presented as means \pm standard deviations. One-way analysis of variance (ANOVA) at $\mathrm{P}<0.05$ was used to determine statistically significant differences in the mean concentrations of metals among groups of garlic bulb and leaf samples. Pearson's correlation analysis was also applied 
to test the correlation between metals in garlic bulb and leaf samples. A probability level of $\mathrm{P}<0.05$ was considered statistically significant. All statistical analyses were done by SPSS version 16.0 software for windows.

\section{Results and Discussion}

\subsection{Method Validation Results}

\subsubsection{Calibration Curves, Limit of Detection and Limit of Quantitation}

Table 1 shows the wavelength used for the ICP-OES elemental analysis, the calibration curve equation, the correlation coefficients, the limits of detection (LOD), and limits of quantitation (LOQ) of the trace elements analyzed in the garlic bulb and leaf samples.

For all analytes, the analytical curves showed correlation coefficients $(R)$ values higher than 0.999 , indicating a good linear correlation between the analytical signal and the analyte concentration.

From Table 1, the limit of detection (LOD) values for all the metals analyzed ranged from $0.1-0.8 \mu \mathrm{g} / \mathrm{g}$ and the limit of quantitation (LOQ) values for all the metals analyzed ranged from $0.3-2.5 \mu \mathrm{g} / \mathrm{g}$. The LOD and LOQ method obtained were low enough to detect the presence of metals of interest at trace levels in both samples.

Table 1. Wavelength of detection, calibration curve equation, correlation coefficient (R) of the calibration curves, limit of detection (LOD) and limit of quantitation (LOQ) obtained for each element.

\begin{tabular}{lllll}
\hline Element & Wavelength $(\mathbf{n m})$ & Calibration equation & R & LOD $(\boldsymbol{\mu g} / \mathbf{g})$ \\
\hline $\mathrm{Fe}$ & 238.2 & $\mathrm{Y}=2068.4 \mathrm{x}+18.7$ & 0.9998 & 0.8 \\
$\mathrm{Zn}$ & 206.2 & $\mathrm{Y}=4226.9 \mathrm{x}+26.3$ & 0.9999 & 0.3 \\
$\mathrm{Mn}$ & 294.9 & $\mathrm{Y}=75560.8 \mathrm{x}+76.3$ & 0.9999 & 0.3 \\
$\mathrm{Cu}$ & 324.7 & $\mathrm{Y}=22876.2 \mathrm{x}+180.1$ & 0.9999 & 0.2 \\
$\mathrm{Mo}$ & 201.5 & $\mathrm{Y}=2295.5 \mathrm{x}+24.8$ & 0.9998 & 0.3 \\
$\mathrm{Co}$ & 236.4 & $\mathrm{Y}=2348.0 \mathrm{x}+21.8$ & 0.9999 & 0.3 \\
$\mathrm{Ni}$ & 221.6 & $\mathrm{Y}=2068.4 \mathrm{x}+18.7$ & 0.9999 & 0.6 \\
$\mathrm{Cr}$ & 206.5 & $\mathrm{Y}=4570.1 \mathrm{x}+60.3$ & 0.9999 & 0.6 \\
$\mathrm{~Pb}$ & 283.3 & $\mathrm{Y}=1050.3 \mathrm{x}+23.4$ & 0.9999 & 0.5 \\
$\mathrm{Cd}$ & 214.4 & $\mathrm{Y}=1617.2 \mathrm{x}+17.8$ & 0.9997 & 0.3 \\
\hline
\end{tabular}

\subsubsection{Precision and Accuracy}

The precision and accuracy of the proposed method were evaluated by means of matrix spike recovery tests. The recovery values of triplicate analysis of the matrix spike garlic bulb and leaf samples were calculated using equation 1 and the RSD values were calculated using equation 2 and the results are presented in Table 2 and 3 respectively.

Table 2. Recovery and precision test results of metals for garlic bulb matrix spike sample.

\begin{tabular}{|c|c|c|c|c|c|}
\hline \multirow{2}{*}{ Metals } & Conc. in sample & Amount added & Conc. in spiked & Recovery & RSD \\
\hline & $(\mu \mathrm{g} / \mathrm{g})$ & $(\mu \mathrm{g} / \mathrm{g})$ & sample $(\mu \mathrm{g} / \mathrm{g})$ & $(\%)$ & $(\%)$ \\
\hline $\mathrm{Na}$ & $360 \pm 8.16$ & 400 & $734.2 \pm 2.10$ & $93.55 \pm 3.21$ & 3.43 \\
\hline K & $9080 \pm 143.3$ & 400 & $9488 \pm 4.20$ & $102.00 \pm 2.74$ & 2.69 \\
\hline $\mathrm{Ca}$ & $1211 \pm 47.28$ & 100 & $1301.3 \pm 7.34$ & $90.30 \pm 7.38$ & 8.17 \\
\hline $\mathrm{Mg}$ & $876 \pm 57.45$ & 100 & $967.4 \pm 9.16$ & $91.40 \pm 9.12$ & 9.98 \\
\hline $\mathrm{Fe}$ & $89.56 \pm 0.09$ & 100 & $180.7 \pm 4.72$ & $91.14 \pm 4.63$ & 5.08 \\
\hline $\mathrm{Zn}$ & $31.68 \pm 0.05$ & 100 & $124.2 \pm 1.15$ & $92.52 \pm 2.50$ & 2.70 \\
\hline $\mathrm{Cu}$ & $4.21 \pm 0.16$ & 100 & $99.8 \pm 2.82$ & $95.59 \pm 2.71$ & 2.84 \\
\hline Mo & $2.08 \pm 0.18$ & 100 & $95.3 \pm 1.17$ & $93.20 \pm 4.11$ & 4.41 \\
\hline Co & $0.85 \pm 0.09$ & 100 & $92.2 \pm 3.54$ & $91.35 \pm 3.60$ & 3.94 \\
\hline $\mathrm{Ni}$ & $1.45 \pm 0.02$ & 100 & $94.0 \pm 5.68$ & $92.55 \pm 7.09$ & 7.66 \\
\hline $\mathrm{Cr}$ & $0.54 \pm 0.06$ & 100 & $90.96 \pm 1.63$ & $90.42 \pm 2.16$ & 2.39 \\
\hline $\mathrm{Pb}$ & $2.02 \pm 0.56$ & 100 & $93.27 \pm 1.45$ & $91.25 \pm 5.08$ & 5.57 \\
\hline $\mathrm{Cd}$ & $0.16 \pm 0.05$ & 100 & $93.78 \pm 2.71$ & $93.62 \pm 3.24$ & 3.46 \\
\hline
\end{tabular}

Table 3. Recovery and precision test results of metals for garlic leaf matrix spike sample.

\begin{tabular}{|c|c|c|c|c|c|}
\hline \multirow{2}{*}{ Metals } & Conc. in sample & Amount added & Conc. in spiked & Recovery & RSD \\
\hline & $(\mu \mathrm{g} / \mathrm{g})$ & $(\mu \mathrm{g} / \mathrm{g})$ & sample $(\mu \mathrm{g} / \mathrm{g})$ & $(\%)$ & $(\%)$ \\
\hline $\mathrm{Na}$ & $730 \pm 8.16$ & 400 & $1106.4 \pm 3.41$ & $94.10 \pm 4.26$ & 4.53 \\
\hline K & $12520 \pm 165.1$ & 400 & $12915.2 \pm 5.13$ & $98.80 \pm 3.18$ & 3.22 \\
\hline $\mathrm{Ca}$ & $1250 \pm 81.32$ & 100 & $1342.7 \pm 2.45$ & $92.70 \pm 6.27$ & 6.76 \\
\hline $\mathrm{Mg}$ & $942 \pm 65.21$ & 100 & $1033.4 \pm 7.29$ & $91.40 \pm 1.54$ & 1.68 \\
\hline $\mathrm{Fe}$ & $94.20 \pm 1.89$ & 100 & $185.51 \pm 4.72$ & $91.31 \pm 5.51$ & 6.03 \\
\hline $\mathrm{Zn}$ & $49.10 \pm 0.26$ & 100 & $141.2 \pm 2.68$ & $92.10 \pm 3.47$ & 3.77 \\
\hline $\mathrm{Mn}$ & $26.74 \pm 0.09$ & 100 & $118.0 \pm 2.43$ & $91.26 \pm 4.55$ & 4.99 \\
\hline $\mathrm{Cu}$ & $8.44 \pm 2.13$ & 100 & $105.3 \pm 3.16$ & $96.86 \pm 2.16$ & 2.23 \\
\hline
\end{tabular}




\begin{tabular}{llllll}
\hline \multirow{2}{*}{ Metals } & Conc. in sample & Amount added & Conc. in spiked & Recovery & RSD \\
\cline { 2 - 6 } & $(\boldsymbol{\mu g} / \mathbf{g})$ & $(\boldsymbol{\mu g} / \mathbf{g})$ & sample $(\boldsymbol{\mu g} / \mathbf{g})$ & $\mathbf{( \% )}$ & $\mathbf{( \% )}$ \\
\hline $\mathrm{Mo}$ & $2.27 \pm 0.07$ & 100 & $97.1 \pm 5.62$ & $94.83 \pm 2.53$ & 2.67 \\
$\mathrm{Co}$ & $2.09 \pm 0.14$ & 100 & $94.35 \pm 4.37$ & $92.26 \pm 5.14$ & 5.57 \\
$\mathrm{Ni}$ & $2.17 \pm 0.01$ & 100 & $92.7 \pm 7.21$ & $90.53 \pm 8.90$ & 9.83 \\
$\mathrm{Cr}$ & $1.51 \pm 0.23$ & 100 & $95.3 \pm 3.72$ & $93.79 \pm 6.24$ & 6.65 \\
$\mathrm{~Pb}$ & $2.48 \pm 0.41$ & 100 & $93.54 \pm 1.45$ & $91.06 \pm 3.79$ & 4.16 \\
$\mathrm{Cd}$ & $0.17 \pm 0.06$ & 100 & $93.07 \pm 3.72$ & $92.90 \pm 2.18$ \\
\hline
\end{tabular}

As it can be seen in Table 2, the percentage recovery of the metal analysis in the garlic bulb samples ranged between 90.30-102.00\% and the RSD values ranged between 1.96 $9.98 \%$. From Table 3, percentage recovery of the metal analysis in the garlic leaf ranged between $90.53-98.80 \%$ and the RSD values ranged between $1.68-9.83 \%$. The matrix spike recovery obtained in this study falls within the acceptable range of $90-110 \%$ for a good recovery study. The high percentage recovery obtained from the study validates the accuracy of the method and the reliability of the levels of metal concentration in this study. The RSD values of the samples were $<10 \%$, indicating that that the proposed method was precise.

\subsubsection{Calibration Control}

Analysis of metal standard solution of mid-point calibration curves after every 10 sample and at the end of sample run shows that each analyte falls $\pm 10 \%$ of the expected value. This indicates that the sample analysis is within the control limits.

\subsubsection{Contamination Control}

Method blanks were run to identify and correct systematic errors due to impurities in the reagents and contamination in the glassware and instrumentation. The analysis results revealed that there were no readings above the method detection limits of the metals. Hence, it can be concluded that the analytical method was free of overall laboratory contamination.

\subsubsection{Laboratory Control Sample Results}

Table 4. Recovery and precision test results for the laboratory control samples.

\begin{tabular}{lllll}
\hline \multirow{2}{*}{ Metals } & Amount added & Conc. in spiked & Recovery & RSD \\
\cline { 2 - 5 } & $(\boldsymbol{\mu g} / \mathbf{g})$ & sample $(\boldsymbol{\mu g} / \mathbf{g})$ & $\mathbf{( \% )}$ & $\mathbf{( \% )}$ \\
\hline $\mathrm{Na}$ & 400 & $392.4 \pm 1.23$ & $98.08 \pm 2.47$ & 2.52 \\
$\mathrm{~K}$ & 400 & $374.48 \pm 2.15$ & $93.56 \pm 5.04$ & 5.39 \\
$\mathrm{Ca}$ & 100 & $90.41 \pm 2.37$ & $90.34 \pm 6.21$ & 6.87 \\
$\mathrm{Mg}$ & 100 & $93.41 \pm 1.86$ & $93.36 \pm 3.85$ & 4.12 \\
$\mathrm{Fe}$ & 100 & $94.75 \pm 5.18$ & $94.68 \pm 1.97$ & 2.08 \\
$\mathrm{Zn}$ & 100 & $101.25 \pm 7.15$ & $101.19 \pm 3.16$ & 3.12 \\
$\mathrm{Mn}$ & 100 & $90.63 \pm 8.65$ & $90.56 \pm 8.94$ & 9.87 \\
$\mathrm{Cu}$ & 100 & $99.82 \pm 7.23$ & $99.65 \pm 3.15$ & 3.16 \\
$\mathrm{Mo}$ & 100 & $90.85 \pm 3.16$ & $90.79 \pm 5.42$ & 5.97 \\
$\mathrm{Co}$ & 100 & $91.27 \pm 4.20$ & $91.20 \pm 1.94$ & 2.13 \\
$\mathrm{Ni}$ & 100 & $92.83 \pm 3.17$ & $92.75 \pm 8.43$ & 9.09 \\
$\mathrm{Cr}$ & 100 & $91.66 \pm 1.96$ & $91.58 \pm 2.16$ & 2.36 \\
$\mathrm{~Pb}$ & 100 & $90.79 \pm 2.47$ & $90.72 \pm 3.43$ & 3.78 \\
$\mathrm{Cd}$ & 100 & $92.71 \pm 1.58$ & $92.65 \pm 2.98$ & 3.22 \\
\hline
\end{tabular}

Laboratory control sample recoveries and relative standard deviations were calculated for the triplicate analysis of each analyte using equation 5 and 2 respectively. The results are summarized in Table 4. As can be seen from the table, the percent recovery values of laboratory control sample (LCS) results lied in the range of $90.34-101.19 \%$ and the RSD values ranged from $2.08-9.87 \%$. The percent recovery obtained in this study falls within the normal acceptable range of $90-110 \%$ for a good LCS recovery study and $\leq 10 \%$ for RSD. These results showed that the analytical method possesses the required precision and accuracy.

\subsection{Results of the Determination of Essential and Non- Essential Metals}

\subsubsection{Levels of Metals in Garlic (Allium sativum L.) Bulb Samples}

In the present study, the mean concentrations of the studied essential and non-essential metals in garlic (Allium sativum L.) bulb are given in Table 5 .

As can be seen from Table 5, the sodium content in the garlic bulb samples ranged from 217 to $366.7 \mathrm{mg} / \mathrm{kg}$. The lowest concentration of sodium $(217 \mathrm{mg} / \mathrm{kg})$ was found in garlic bulb collected from Qibafkube site and highest concentration of sodium $(366.7 \mathrm{mg} / \mathrm{kg})$ was found in garlic bulb collected from Gosu Qora site. Whereas, Elamu Goromti and Awaro Qora garlic bulb contains 343 and 360 $\mathrm{mg} / \mathrm{kg}$ respectively. The levels indicated that $\mathrm{Na}$ is the least accumulated metal by garlic bulb among the four macroelements determined in all the samples.

The concentrations of potassium in the garlic bulb samples were found higher than all the metals analyzed. Mean potassium concentration ranged from $9080 \mathrm{mg} / \mathrm{kg}$ to 12060 $\mathrm{mg} / \mathrm{kg}$. The lowest and highest concentration of $\mathrm{K}$ was found in Awaro Qora (9080 mg/kg) and Elamu Goromti (12060 $\mathrm{mg} / \mathrm{kg}$ sites respectively. The amount of potassium in Gosu Qora and Qibafkube garlic samples were $10258 \mathrm{mg} / \mathrm{kg}$ and $11580 \mathrm{mg} / \mathrm{kg}$ respectively (Table 5) However, there was significant difference $(\mathrm{p}<0.05)$ in the content of potassium between the sampling sites.

Calcium was the second most accumulated essential metal next to potassium in the garlic bulb. The average concentration of calcium (Table 5) in the garlic bulb samples ranged from $1018 \mathrm{mg} / \mathrm{kg}$ in Elamu Goromti garlic bulb to $1286 \mathrm{mg} / \mathrm{kg}$ in Gosu Qora garlic bulb. The calcium content of Qibafkube and Awaro Qora garlic bulb were 1079 and $1211 \mathrm{mg} / \mathrm{kg}$ respectively.

The level of magnesium in garlic bulbs ranged from 802 to $992.6 \mathrm{mg} / \mathrm{kg}$. However, there was significant difference $(\mathrm{p}<$ 
0.05) in the content of $\mathrm{Mg}$ between the sampling sites. The lowest concentration $(802 \mathrm{mg} / \mathrm{kg})$ being in garlic collected from Qibafkube site and the highest concentration (992.6 $\mathrm{mg} / \mathrm{kg}$ ) in garlic collected from Gosu Qora site. The amount of $\mathrm{Mg}$ in Elamu Goromti and Awaro Qora garlic bulb were $854 \mathrm{mg} / \mathrm{kg}$ and $876 \mathrm{mg} / \mathrm{kg}$ respectively.

The results in Table 5 reveal that the concentrations of iron in the garlic bulb samples were $63.44 \mathrm{mg} / \mathrm{kg}$ in Elamu Goromti garlic bulb, $85.82 \mathrm{mg} / \mathrm{kg}$ in Qibafkube garlic bulb, $89.56 \mathrm{mg} / \mathrm{kg}$ in Awaro Qora garlic bulb and $91.24 \mathrm{mg} / \mathrm{kg}$ in Gosu Qora garlic bulb. The results found were lower than the FAO/WHO maximum permissible limit for medicinal plant that is $425 \mathrm{mg} / \mathrm{kg}$ [23]. One-way ANOVA test showed that there was significant difference $(\mathrm{P}<0.05)$ among the mean concentrations of iron in the garlic bulb.

Zinc level in garlic bulb was in the range of 31.17-35.39 $\mathrm{mg} / \mathrm{kg}$ as shown in Table 5. The lowest zinc content was obtained in garlic bulbs collected from Gosu Qora site and the highest in garlic bulb collected from Qibafkube site. However, there was no significant variation $(p>0.05)$ in the content of $\mathrm{Zn}$ between the sampling sites. The FAO/WHO recommended limit of zinc in medicinal plant is $100 \mathrm{mg} / \mathrm{kg}$ [23].

As evident from Table 5, the manganese contents of garlic bulb in all the sampling sites were almost similar except Gosu site. The obtained results are $5.27 \mathrm{mg} / \mathrm{kg}$ for Qibafkube, $5.38 \mathrm{mg} / \mathrm{kg}$ for Awaro Qora, $5.49 \mathrm{mg} / \mathrm{kg}$ for Elamu Goromti, and $7.51 \mathrm{mg} / \mathrm{kg}$ for Gosu Qora garlic bulb. However, there was no significant difference $(p>0.05)$ in the content of Mn between the sampling sites except Gosu Qora site. The level of Mn found in this study was lower than the FAO/WHO (2001) [23] recommended limit of $500 \mathrm{mg} / \mathrm{kg}$.

The concentration of copper in garlic bulb samples ranged between 4.21 to $7.16 \mathrm{mg} / \mathrm{kg}$ (Table 5). The lowest concentration of copper $(\mathrm{Cu})$ was found in garlic bulb sample collected from Awaro Qora site while the highest concentration was found in Qibafkube site. The content of $\mathrm{Cu}$ reported in this study was generally lower than the permissible levels by FAO/WHO (2001) in vegetables [23]. One-way ANOVA test showed that there was significant difference $(\mathrm{P}<0.05)$ among the mean concentrations of $\mathrm{Cu}$ in the garlic bulb samples.

Table 5 shows the molybdenum level in garlic bulb was in the range of $1.06-2.08 \mathrm{mg} / \mathrm{kg}$. The lowest molybdenum content was obtained in garlic bulb collected from Elamu Goromti site $(1.06 \mathrm{mg} / \mathrm{kg})$ and the highest in garlic bulb collected from Awaro Qora site $(2.08 \mathrm{mg} / \mathrm{kg})$. The concentration of molybdenum in Gosu Qora and Qibafkube garlic bulbs were 1.33 and $1.47 \mathrm{mg} / \mathrm{kg}$ respectively. However, there was no significant variation $(p>0.05)$ in the level of molybdenum between the sampling sites.

The results of cobalt concentration in garlic bulb samples were $0.610 .85,0.99$ and $1.49 \mathrm{mg} / \mathrm{kg}$ in sample sites of Elamu Goromti, Awaro Qora, Qibafkube and Gosu Qora, respectively (Table 5). The level of cobalt found in this study was lower than the FAO/WHO (2001) [23] recommended limit that is $50 \mathrm{mg} / \mathrm{kg}$. One-way ANOVA test showed that there was significant difference $(\mathrm{P}<0.05)$ among the mean concentrations of $\mathrm{Co}$ in the garlic bulb samples.

As can be shown in Table 5, the average concentrations of nickel in garlic bulb grown in Awaro Qora, Gosu Qora, Qibafkube and Elamu Goromti were 1.45, 2.45, 3.78 and $3.69 \mathrm{mg} / \mathrm{kg}$, respectively. One-way ANOVA test showed that there was significant difference $(\mathrm{P}<0.05)$ among the mean concentrations of nickel in the garlic bulb samples.

From Table 5, the mean concentrations of chromium in the garlic bulb samples were $0.54 \mathrm{mg} / \mathrm{kg}$ in Awaro Qora garlic bulb, $1.31 \mathrm{mg} / \mathrm{kg}$ in Gosu Qora garlic bulb, $0.81 \mathrm{mg} / \mathrm{kg}$ in Qibafkube garlic bulb, and $0.47 \mathrm{mg} / \mathrm{kg}$ in Elamu Goromti garlic bulb. The concentrations of $\mathrm{Cr}$ obtained in this study were lower than the FAO/WHO (2001) [23] recommended maximum limit for plant that is $2.3 \mathrm{mg} / \mathrm{kg}$. One-way ANOVA test showed that there was significant difference $(\mathrm{P}<0.05)$ among the mean concentrations of $\mathrm{Cr}$ in the garlic bulb samples.

In the studied garlic bulb samples, the results of lead concentrations were 2.02, 2.51, 1.75 and $1.07 \mathrm{mg} / \mathrm{kg}$ in sample sites of Awaro Qora, Gosu Qora, Qibafkube and Elamu Goromti, respectively (Table 5). The relatively high levels of lead might have resulted from accumulation of lead through air pollution and from some pesticides, such as lead arsenates applied during cultivation. The WHO (1998) [24] recommended maximum limit of $\mathrm{Pb}$ for medicinal plant is 10 $\mathrm{mg} / \mathrm{kg}$. The levels of lead found in this study were lower than this maximum permissible limit.

As can be seen from Table 5, the mean concentrations of cadmium in the garlic bulb samples were $0.16 \mathrm{mg} / \mathrm{kg}$ in Awaro Qora garlic bulb, $0.12 \mathrm{mg} / \mathrm{kg}$ in Gosu Qora garlic bulb, $0.10 \mathrm{mg} / \mathrm{kg}$ in Qibafkube garlic bulb, and $0.11 \mathrm{mg} / \mathrm{kg}$ in Elamu Goromti garlic bulb. The high level of cadmium might be due to the use of cadmium-containing phosphate fertilizers and contamination from cadmium-containing dusts. The concentrations of cadmium obtained in this study were lower than the WHO (1998) [24] recommended maximum limit for medicinal plant that is $0.3 \mathrm{mg} / \mathrm{kg}$.

In this study, we can observe that $\mathrm{Na}, \mathrm{Ca}, \mathrm{Mg}, \mathrm{Fe}, \mathrm{Mn}, \mathrm{Co}$, $\mathrm{Cr}$ and $\mathrm{Pb}$ were found to be present in highest concentration in the garlic bulb sample taken from Gosu Qora site. In the same manner, $\mathrm{Zn}$ and $\mathrm{Cu}$ were found to be highest in Qibafkube garlic bulb. $\mathrm{K}$ and $\mathrm{Ni}$ were highest in Elamu Goromti garlic bulb. The highest value of $\mathrm{Mo}$ and $\mathrm{Cd}$ were found in Awaro Qora garlic bulb.

The result of the present study showed a high level of macro elements accumulation in the garlic bulb. In general, the mean concentrations of metals in garlic (Allium sativum) bulb collected from all sampling site decreased in the order of: $\mathrm{K}>\mathrm{Ca}>\mathrm{Mg}>\mathrm{Na}>\mathrm{Fe}>\mathrm{Zn}>\mathrm{Mn}>\mathrm{Cu}>\mathrm{Ni}>\mathrm{Pb}>$ $\mathrm{Mo}>\mathrm{Co}>\mathrm{Cr}>\mathrm{Cd}$. 
Table 5. Mean concentrations of metals ( $\mathrm{mg} / \mathrm{kg}$ dry weight) of garlic bulb samples.

\begin{tabular}{llllll}
\hline & mean \pm sd, $\mathbf{n}=\mathbf{3}$. & & & & \\
\hline & Sample Sites & & & Max. safe \\
\hline Metals & Awaro Qora & Gosu Qora & Qibafkube & Elamu Goromti & Limit in \\
\hline & garlic bulb & garlic bulb & garlic bulb & garlic bulb & Plant (mg/kg) \\
\hline $\mathrm{Na}$ & $360 \pm 8.16$ & $366.7 \pm 4.71$ & $217 \pm 36.80$ & $343 \pm 23.57$ & NA \\
$\mathrm{K}$ & $9080 \pm 143.3$ & $10258 \pm 125.6$ & $11580 \pm 158$ & $12060 \pm 122.3$ & $\mathrm{NA}$ \\
$\mathrm{Ca}$ & $1211 \pm 47.28$ & $1286 \pm 94.12$ & $1079 \pm 78.29$ & $1018 \pm 67.73$ & $\mathrm{NA}$ \\
$\mathrm{Mg}$ & $876 \pm 57.45$ & $992.6 \pm 85.34$ & $802 \pm 42.81$ & $854 \pm 38.56$ & NA \\
$\mathrm{Fe}$ & $89.56 \pm 0.09$ & $91.24 \pm 0.18$ & $85.82 \pm 0.58$ & $63.44 \pm 0.53$ & $425^{\mathrm{a}}$ \\
$\mathrm{Zn}$ & $31.68 \pm 0.05$ & $31.17 \pm 0.28$ & $35.39 \pm 0.98$ & $34.39 \pm 0.06$ & $100^{\mathrm{a}}$ \\
$\mathrm{Mn}$ & $5.38 \pm 0.05$ & $7.51 \pm 0.13$ & $5.27 \pm 0.04$ & $5.49 \pm 0.06$ & $500^{\mathrm{a}}$ \\
$\mathrm{Cu}$ & $4.21 \pm 0.16$ & $5.16 \pm 0.22$ & $7.16 \pm 0.25$ & $5.01 \pm 0.18$ & $73^{\mathrm{a}}$ \\
$\mathrm{Mo}$ & $2.08 \pm 0.18$ & $1.33 \pm 0.19$ & $1.47 \pm 0.27$ & $1.06 \pm 0.35$ & $\mathrm{NA}$ \\
$\mathrm{Co}$ & $0.85 \pm 0.09$ & $1.49 \pm 0.15$ & $0.99 \pm 0.09$ & $0.61 \pm 0.07$ & $50^{\mathrm{a}}$ \\
$\mathrm{Ni}$ & $1.45 \pm 0.02$ & $2.45 \pm 0.43$ & $3.78 \pm 0.29$ & $3.69 \pm 0.41$ & $67^{\mathrm{a}}$ \\
$\mathrm{Cr}$ & $0.54 \pm 0.06$ & $1.31 \pm 0.21$ & $0.81 \pm 0.17$ & $0.47 \pm 0.04$ & $2.3^{\mathrm{a}}$ \\
$\mathrm{Pb}$ & $2.02 \pm 0.56$ & $2.51 \pm 0.13$ & $1.75 \pm 0.11$ & $1.07 \pm 0.59$ & $10^{\mathrm{b}}$ \\
$\mathrm{Cd}$ & $0.16 \pm 0.05$ & $0.12 \pm 0.04$ & $0.10 \pm 0.02$ & $0.11 \pm 0.02$ & $0.3^{\mathrm{b}}$ \\
\hline $\mathrm{Key}$ & & & &
\end{tabular}

Key: ${ }^{a}$ Source: [23], ${ }^{\mathrm{b}}$ Source: [24], NA= not available, sd = standard deviation.

\subsubsection{Levels of Metals in Garlic (Allium sativum L.) Leaf Samples}

In the present study, the mean concentrations of the studied essential and non-essential metals in garlic (Allium sativum L.) leaf are given in Table 6.

As can be seen from Table 6, the sodium content in the garlic leaf samples ranged from 463 to $730 \mathrm{mg} / \mathrm{kg}$. The lowest concentration of $\mathrm{Na}(433 \mathrm{mg} / \mathrm{kg})$ was found in garlic leaf collected from Qibafkube site and highest concentration of $\mathrm{Na}(730 \mathrm{mg} / \mathrm{kg})$ was found in garlic leaf collected from Awaro Qora. Whereas, Gosu Qora and Elamu Goromti garlic leaf contains 693 and $503 \mathrm{mg} / \mathrm{kg}$ respectively. The result indicated that $\mathrm{Na}$ is the least accumulated metal by garlic leaf among the four macro elements analyzed.

The concentration of potassium in the garlic leaf samples were found higher than all the metals analyzed. Mean potassium concentration ranged from $11370 \mathrm{mg} / \mathrm{kg}$ to 12860 $\mathrm{mg} / \mathrm{kg}$. However, there was significant difference $(\mathrm{p}<0.05)$ in the content of $\mathrm{K}$ between the sampling sites. The lowest and highest concentration of potassium was found in Gosu Qora $(11370 \mathrm{mg} / \mathrm{kg})$ and Elamu Goromti $(12860 \mathrm{mg} / \mathrm{kg})$ sites. The amount of K in Awaro Qora and Qibafkube garlic leaf were $12520 \mathrm{mg} / \mathrm{kg}$ and $11926 \mathrm{mg} / \mathrm{kg}$ respectively (Table 6).

Calcium was the second most accumulated essential metal next to potassium in garlic leaf samples. The average concentration of calcium in the garlic leaf samples ranged from $1209 \mathrm{mg} / \mathrm{kg}$ in Qibafkube garlic leaf to $1302 \mathrm{mg} / \mathrm{kg}$ in Gosu Qora garlic leaf. The calcium content of Awaro Qora and Elamu Goromti garlic leaf were 1250 and $1264 \mathrm{mg} / \mathrm{kg}$ respectively (Table 6).

The level of magnesium in garlic leaf ranged from 871 to $994 \mathrm{mg} / \mathrm{kg}$. However, there was significant difference $(\mathrm{p}<$ 0.05 ) in the content of magnesium between the sampling sites. The lowest concentration $(871 \mathrm{mg} / \mathrm{kg})$ being in garlic leaf collected from Qibafkube site and the highest concentration $(994 \mathrm{mg} / \mathrm{kg})$ in garlic leaf collected from Gosu
Qora sampling site. The amount of magnesium in Elamu Goromti and Awaro Qora garlic leaf were $894 \mathrm{mg} / \mathrm{kg}$ and 942 $\mathrm{mg} / \mathrm{kg}$ respectively (Table 6 ).

The results in Table 6 reveal that the concentrations of iron in the garlic leaf samples were $72.30 \mathrm{mg} / \mathrm{kg}$ in Elamu Goromti garlic leaf, $86.00 \mathrm{mg} / \mathrm{kg}$ in Qibafkube garlic leaf, $94.20 \mathrm{mg} / \mathrm{kg}$ in Awaro Qora garlic leaf and $108.00 \mathrm{mg} / \mathrm{kg}$ in Gosu Qora garlic leaf. The results found were lower than the FAO/WHO maximum permissible limit for medicinal plant that is $425 \mathrm{mg} / \mathrm{kg}$ [23]. ANOVA test showed that there was significant difference $(\mathrm{P}<0.05)$ among the mean concentrations of $\mathrm{Fe}$ in the garlic leaf samples.

Zinc level in garlic leaf was in the range of 49.1-71.39 $\mathrm{mg} / \mathrm{kg}$ as shown in Table 6. The lowest $\mathrm{Zn}$ content was obtained in garlic leaf collected from Awaro Qora site and the highest in garlic leaf collected from Elamu Goromti site. However, there was significant variation $(p<0.05)$ in the content of $\mathrm{Zn}$ between all the sampling sites. The value of $\mathrm{Zn}$ obtained in this study was less than the FAO/WHO recommended limit of $\mathrm{Zn}$ in medicinal plant that is 100 $\mathrm{mg} / \mathrm{kg}$ [23].

As evident from Table 6, the manganese contents of garlic leaf obtained were $26.74 \mathrm{mg} / \mathrm{kg}$ for Awaro Qora, 33.78 $\mathrm{mg} / \mathrm{kg}$ for Gosu Qora, $58.67 \mathrm{mg} / \mathrm{kg}$ for Qibafkube, and 72.36 $\mathrm{mg} / \mathrm{kg}$ for Elamu Goromti garlic leaf samples. However, there was significant variation $(\mathrm{p}<0.05)$ in the content of $\mathrm{Mn}$ between the sampling sites. The level of $\mathrm{Mn}$ found in this study was lower than the FAO/WHO (2001) recommended limit [23].

The concentration of copper (Table 6) in garlic leaf samples ranged between 5.41 to $8.44 \mathrm{mg} / \mathrm{kg}$. The lowest concentration of $\mathrm{Cu}$ was found in garlic sample collected from Gosu Qora site while the highest concentration was found in Awaro Qora site. The content of $\mathrm{Cu}$ reported in this study was generally lower than the permissible levels by FAO/WHO (2001) [23] in vegetables. One-way ANOVA test 
showed that there was significant difference $(\mathrm{P}<0.05)$ among the mean concentrations of copper in the garlic leaf samples collected from all the sampling sites.

From Table 6, the concentration of molybdenum level in garlic leaf was in the range of $0.84-2.30 \mathrm{mg} / \mathrm{kg}$. The lowest Mo content was obtained in garlic leaf collected from Qibafkube site $(0.84 \mathrm{mg} / \mathrm{kg})$ and the highest in garlic leaf collected from Gosu Qora site $(2.30 \mathrm{mg} / \mathrm{kg})$. The concentration of Awaro Qora and Elamu Goromti garlic leafs were 2.27 and $1.01 \mathrm{mg} / \mathrm{kg}$ respectively. ANOVA test showed that there was significant difference $(\mathrm{P}<0.05)$ among the mean concentrations of Mo in the garlic leaf samples.

The results of cobalt $(\mathrm{Co})$ concentrations were 1.17, 2.09, 3.09 and $4.96 \mathrm{mg} / \mathrm{kg}$ in sample sites of Elamu Goromti, Awaro Qora, Qibafkube and Gosu Qora, respectively (Table $6)$. The level of cobalt found in this study was lower than the FAO/WHO (2001) [23] recommended limit of $50 \mathrm{mg} / \mathrm{kg}$. ANOVA test showed that there was significant difference ( $P$ $<0.05$ ) among the mean concentrations of $\mathrm{Co}$ in the garlic leaf samples.

The average concentrations of nickel in garlic leaf in Awaro Qora, Gosu Qora, Qibafkube and Elamu Goromti were $2.17,3.54,3.51$ and $2.54 \mathrm{mg} / \mathrm{kg}$, respectively (Table 6). One-way ANOVA test showed that there was significant difference $(\mathrm{P}<0.05)$ among the mean concentrations of nickel in the garlic leaf samples.

From Table 6, the mean concentrations of Chromium $(\mathrm{Cr})$ in the garlic samples were $1.51 \mathrm{mg} / \mathrm{kg}$ in Awaro Qora garlic leaf, $2.17 \mathrm{mg} / \mathrm{kg}$ in Gosu Qora garlic leaf, $1.32 \mathrm{mg} / \mathrm{kg}$ in Qibafkube garlic leaf, and $1.20 \mathrm{mg} / \mathrm{kg}$ in Elamu Goromti garlic leaf. However, there was no significant variation ( $p>$ 0.05 ) in the content of $\mathrm{Cr}$ between the sampling sites. The concentrations of $\mathrm{Cr}$ obtained in this study were lower than the FAO/WHO (2001) [23] recommended maximum limit for plant that is $2.3 \mathrm{mg} / \mathrm{kg}$.

In the studied garlic leaf samples, the results of lead concentrations were $2.48,1.87,2.69$ and $2.84 \mathrm{mg} / \mathrm{kg}$ in sample sites of Awaro Qora, Gosu Qora, Qibafkube and Elamu Goromti, respectively (Table 6). However, there was no significant variation $(\mathrm{p}>0.05)$ in the content of $\mathrm{Pb}$ between the sampling sites. The relatively high levels of $\mathrm{Pb}$ might have resulted from accumulation of $\mathrm{Pb}$ through air pollution and from some pesticides, such as lead arsenates applied during cultivation. The levels of $\mathrm{Pb}$ found in this study were lower than the WHO (1998) [24] recommended maximum limit for medicinal plant that is $10 \mathrm{mg} / \mathrm{kg}$.

From Table 6, the mean concentrations of cadmium $(\mathrm{Cd})$ in the garlic leaf in Awaro Qora, Gosu Qora, Qibafkube and Elamu Goromti were $0.17,0.18,0.14$ and $0.12 \mathrm{mg} / \mathrm{kg}$, respectively. The relatively high level of $\mathrm{Cd}$ might be due to the use of cadmium-containing phosphate fertilizers and contamination from cadmium-containing dusts. The concentrations of cadmium obtained in this study were lower than the WHO (1998) [24] recommended maximum limit for medicinal plant that is $0.3 \mathrm{mg} / \mathrm{kg}$.

In this study, we can observe that $\mathrm{Ca}, \mathrm{Mg}, \mathrm{Fe}, \mathrm{Mo}, \mathrm{Co}, \mathrm{Ni}$, $\mathrm{Cr}$ and $\mathrm{Cd}$ were found to be present in highest concentration in the garlic leaf sample taken from Gosu Qora site. In the same manner, $\mathrm{Na}$ and $\mathrm{Cu}$ were found to be highest in Awaro Qora garlic leaf. The highest value of $\mathrm{K}, \mathrm{Zn}, \mathrm{Mn}$ and $\mathrm{Pb}$ was found in Elamu Goromti garlic leaf sample.

The result of the present study showed a high level of macroelements accumulation in the garlic leaf. In addition, the results show that the levels of elements were higher in the leaves than the bulbs. In general, the mean concentrations of metals in garlic leaf collected from all sampling site decreased in the order of: $\mathrm{K}>\mathrm{Ca}>\mathrm{Mg}>\mathrm{Na}>\mathrm{Fe}>\mathrm{Zn}>$ $\mathrm{Mn}>\mathrm{Cu}>\mathrm{Ni}>\mathrm{Co}>\mathrm{Pb}>\mathrm{Mo}>\mathrm{Cr}>\mathrm{Cd}$.

Table 6. Mean concentrations of metals ( $\mathrm{mg} / \mathrm{kg}$ dry weight) of garlic leaf samples.

\begin{tabular}{|c|c|c|c|c|c|}
\hline & \multicolumn{5}{|c|}{ mean $\pm s d, n=3$} \\
\hline \multirow[b]{2}{*}{ Metals } & Sample Sites & & & & Max. safe \\
\hline & Awaro Qora & Gosu Qora & Qibafkube & Elamu Goromti & Limit in Plant \\
\hline & garlic leaf & garlic leaf & garlic leaf & garlic leaf & $(\mathrm{mg} / \mathrm{kg})$ \\
\hline $\mathrm{Na}$ & $730 \pm 8.16$ & $693 \pm 33.99$ & $463 \pm 0.69$ & $503 \pm 52.49$ & NA \\
\hline $\mathrm{K}$ & $12520 \pm 165$ & $11370 \pm 111$ & $11926 \pm 277$ & $12860 \pm 257.8$ & NA \\
\hline $\mathrm{Ca}$ & $1250 \pm 81.32$ & $1302 \pm 76.34$ & $1209 \pm 78.5$ & $1264 \pm 79.86$ & NA \\
\hline $\mathrm{Mg}$ & $942 \pm 65.21$ & $994 \pm 78.53$ & $871 \pm 67.43$ & $894 \pm 65.28$ & NA \\
\hline $\mathrm{Fe}$ & $94.20 \pm 1.89$ & $108 \pm 3.12$ & $86 \pm 1.17$ & $72.30 \pm 0.81$ & $425^{\mathrm{a}}$ \\
\hline $\mathrm{Zn}$ & $49.10 \pm 0.26$ & $56.87 \pm 1.29$ & $68.14 \pm 1.59$ & $71.39 \pm 0.62$ & $100^{\mathrm{a}}$ \\
\hline $\mathrm{Mn}$ & $26.74 \pm 0.09$ & $33.78 \pm 0.26$ & $58.67 \pm 0.43$ & $72.36 \pm 0.74$ & $500^{\mathrm{a}}$ \\
\hline $\mathrm{Cu}$ & $8.44 \pm 2.13$ & $5.41 \pm 0.18$ & $7.18 \pm 0.41$ & $6.33 \pm 0.33$ & $73^{\mathrm{a}}$ \\
\hline Mo & $2.27 \pm 0.07$ & $2.30 \pm 0.49$ & $0.84 \pm 0.05$ & $1.01 \pm 0.05$ & NA \\
\hline Co & $2.09 \pm 0.14$ & $4.96 \pm 0.84$ & $3.09 \pm 0.21$ & $1.17 \pm 0.10$ & $50^{\mathrm{a}}$ \\
\hline $\mathrm{Ni}$ & $2.17 \pm 0.01$ & $3.54 \pm 0.46$ & $3.51 \pm 0.30$ & $2.54 \pm 0.31$ & $67^{\mathrm{a}}$ \\
\hline $\mathrm{Cr}$ & $1.51 \pm 0.23$ & $2.17 \pm 0.05$ & $1.32 \pm 0.16$ & $1.20 \pm 0.13$ & $2.3^{\mathrm{a}}$ \\
\hline $\mathrm{Pb}$ & $2.48 \pm 0.41$ & $1.87 \pm 0.19$ & $2.69 \pm 0.58$ & $2.84 \pm 0.63$ & $10^{\mathrm{b}}$ \\
\hline $\mathrm{Cd}$ & $0.17 \pm 0.41$ & $0.18 \pm 0.19$ & $0.14 \pm 0.58$ & $0.12 \pm 0.63$ & $0.3^{\mathrm{b}}$ \\
\hline
\end{tabular}

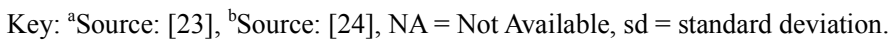




\subsection{Statistical Analysis}

\subsubsection{Analysis of Variance}

Variations in the mean levels of metals between the samples were tested using one-way ANOVA. The results of metal concentration indicated that significant differences were obtained $(\mathrm{p}<0.05)$ at $95 \%$ confidence levels for $\mathrm{Na}, \mathrm{K}$, $\mathrm{Ca}, \mathrm{Mg}, \mathrm{Fe}, \mathrm{Cu}, \mathrm{Co}, \mathrm{Ni}, \mathrm{Cr}$ and $\mathrm{Pb}$ in garlic bulb samples collected from all the four sites. However, the variations of $\mathrm{Zn}, \mathrm{Mn}, \mathrm{Mo}$ and $\mathrm{Cd}$ for the garlic bulb samples were not significant $(\mathrm{p}>0.05)$. Similarly, significant differences were obtained $(\mathrm{p}<0.05)$ in the levels of $\mathrm{Na}, \mathrm{K}, \mathrm{Ca}, \mathrm{Mg}, \mathrm{Fe}, \mathrm{Zn}$, $\mathrm{Mn}, \mathrm{Cu}, \mathrm{Mo}, \mathrm{Co}, \mathrm{Ni}$, and $\mathrm{Cd}$ in garlic leaf samples collected from all the four sites. However, the variations of $\mathrm{Cr}$ and $\mathrm{Pb}$ for the garlic leaf samples were not significant $(\mathrm{p}>0.05)$. This significance difference and increase in elemental concentrations may be due to application of various types of pesticides and fertilizer, the type of water present in the soil, and difference in physicochemical nature of the soil.

\subsubsection{Pearson Correlation}

The significant relationships between concentration of essential and non-essential metals in Allium sativum bulb and leaf samples were further substantiated by performing correlation analysis. Pearson's correlation coefficients of mean level of metals from all the sample sites $(n=4)$ between garlic bulb and garlic leaf was analyzed at $p=0.05$.

According to literatures, if correlation coefficient is 1.0, there is complete dependency, if it is 0.0 there is no relationship, if it is negative, both are said to be correlated in opposite direction. However, if correlation is $>0.50$, it is said to be significant and less significant when $<0.50$ [25].

The values of Pearson correlation coefficients between metal concentrations of garlic bulb and garlic leaf samples are given in Table 7. As can be seen from Table 7, statistically significant positive correlation coefficients for $\mathrm{Na}(\mathrm{r}=0.758), \mathrm{Ca}(\mathrm{r}=0.581), \mathrm{Mg}(\mathrm{r}=0.965), \mathrm{Fe}(\mathrm{r}=0.882)$, Zn $(r=0.862)$, Mo $(r=0.541)$, Co $(r=0.995), C r(r=0.889)$ and $\mathrm{Cd}(0.587)$ were established between metal concentrations in garlic bulb and leaf samples.

From Table 7, there were weak positive correlations for $\mathrm{K}$ $(\mathrm{r}=0.192)$ and $\mathrm{Ni}(\mathrm{r}=0.448)$. There were negative insignificant correlations for $\mathrm{Mn}, \mathrm{Cu}$ and $\mathrm{Pb}$ between garlic bulb and leaf samples. The weak negative insignificant correlation indicates there was weak association between Allium sativum bulb and leaf samples at both locations.

Table 7. Correlation coefficient (r) for metals between garlic bulb and leaf.

\begin{tabular}{llll}
\hline Metals & r & Metals & r \\
\hline $\mathrm{Na}$ & 0.758 & $\mathrm{Cu}$ & -0.151 \\
$\mathrm{~K}$ & 0.192 & $\mathrm{Mo}$ & 0.541 \\
$\mathrm{Ca}$ & 0.581 & $\mathrm{Co}$ & 0.995 \\
$\mathrm{Mg}$ & 0.965 & $\mathrm{Ni}$ & 0.448 \\
$\mathrm{Fe}$ & 0.882 & $\mathrm{Cr}$ & 0.889 \\
$\mathrm{Zn}$ & 0.862 & $\mathrm{~Pb}$ & -0.917 \\
$\mathrm{Mn}$ & -0.418 & $\mathrm{Cd}$ & 0.587 \\
\hline
\end{tabular}

\section{Conclusion}

The levels of essential metals ( $\mathrm{Na}, \mathrm{K}, \mathrm{Ca}, \mathrm{Mg}, \mathrm{Fe}, \mathrm{Zn}, \mathrm{Mn}$, $\mathrm{Cu}, \mathrm{Mo}, \mathrm{Co}, \mathrm{Cr}$ and $\mathrm{Ni}$ ) and non-essential metals $(\mathrm{Cd}$ and $\mathrm{Pb})$ in Allium sativum (garlic) bulb and leaf samples collected from Ambo Woreda, Ethiopia were determined for $\mathrm{Na}$ and $\mathrm{K}$ using flame photometer, $\mathrm{Ca}$ and $\mathrm{Mg}$ by EDTA titration, and the rest of the metals using ICP-OES after wet digestion. The optimized wet digestion method for digestion of the garlic samples were found to be efficient, precise and accurate for the metals analyzed, and it was validated through the recovery experiment and a good percentage recovery was obtained for the essential and non-essential metal determined.

This study revealed that the investigated garlic bulb and leaf samples are good source of essential metals. However, the results show that the levels of metal contents were higher in the leaves than the bulbs. It was generally observed that the results obtained are in agreement with the FAO/WHO guideline (2001) for allowed elemental concentrations in human nutrition: hence the garlic bulb and leaf samples can be consumed without any risk. Furthermore, the present study will give brief information about the mineral contents of garlic bulb and leaf, and these results may serve as a base line data for determination of mineral contents in vegetables in the study area.

In conclusion, it was found that various farming activities and heavy usage of fertilizers and pesticides did not increase the content of toxic metals in the study area. Awareness of people and regular monitoring of levels of these metals in vegetables is essential to prevent the incorporation in the food chain. Further works should be carried out in the soil samples were the vegetables are grown.

\section{Acknowledgments}

The authors would like to thank the Department of Chemistry, and Director, Research, Consultancy and Community Service of Ambo University, Ethiopia, for providing the necessary facilities to conduct this research work.

\section{References}

[1] Kamenetsky, R., Faigenboim, A., Mayer, E. S., Michael, T. B., Gershberg, C., Kimhi, S., Esquira, I., Shalom, S. R., Eshel, D., Rabinowitch, H. D. and Sherman, A. (2015). Integrated transcriptome catalogue and organ-specific profiling of gene expression in fertile garlic (Allium sativum L.). BMC Genomics, 16 (12), 1-15.

[2] Kallel, F., Driss, D., Chaari, F., Belghith, L., Bouaziz, F., Ghorbel, R. and Chaabouni, S. E. (2014). Garlic (Allium sativum L.) husk waste as a potential source of phenolic compounds: Influence of extracting solvents on its antimicrobial and antioxidant properties, Industrial Crops and Products, 62, 34-41. 
[3] Diriba, S. G., Kebede, W., Nigussie, D. R., Getachew, T. and Sharma, J. J. (2013). Postharvest quality and shelf life of garlic bulb as influenced by storage season, soil type and different compound fertilizers. Journal of Postharvest Technology, 1 (1), 69-83.

[4] Deresse, D. (2010). Antibacterial effect of garlic (Allium sativum) on Staphylococcu aureus: An in vitro study. Asian Journal of Medical Sciences, 2 (2), 62-65.

[5] Packia Lekshmi, N. C. J., Viveka, S., Jeeva, S. and Raja Brindha, J. (2015). Antimicrobial Spectrum of Allium Species: A Review. Indian journal of Science, 15 (44), 1-5.

[6] Adekunle, I. M., Olorundare, O. and Nwange, C. (2009). Assessments of lead levels and daily intakes from green leafy vegetables of southwest Nigeria. Nutrition and Food Science, 39 (4), 413-422.

[7] Hellen, L. E., \& Othman, O. C. (2014). Levels of selected heavy metals in soil, tomatoes and selected vegetables from Lushoto district-Tanzania. International Journal of Environmental Monitoring and Analysis, 2 (6), 313-319.

[8] Kachenkom, A. G. and Singh, B. (2006). Heavy metal contamination in vegetables grown in urban and metal smelter contaminated sites in Australia. Water, Air and Soil Pollution, $169(1-4), 101-123$.

[9] Wilson, B. and Pyatt, F. B. (2007). Heavy metal dispersion, persistence, and bioaccumulation around an ancient copper mine situated in Anglesey, UK. Ecotoxicology and Environmental Safety, 66, 224-231.

[10] Tasrina, R. C., Rowshon, A., Mustafizur, A. M. R., Rafiqul, I. and Ali., M. P. (2015). Heavy metals contamination in vegetables and its growing soil. Journal of Environmental Analytical Chemistry, 2 (3), 1-6.

[11] Chailapakul, O., Korsrisakul, S., Siangroh, W. and Grudpan, K. (2007). Fast and simultaneous detection of heavy metals using a simple reliable microchip-electrochemistry route: An alternative approach to food analysis. Talanta, 74, 683-689.

[12] Hamza, N. A. E., Hammad, A.Y. and Eltayeb, M.A. (2013). Adsorption of Metals (Fe(II), $\mathrm{Cr}(\mathrm{III})$ and $\mathrm{Co}(\mathrm{II})$ ) from aqueous solution by using Activated carbon prepared from Mesquite tree. Science Journal of Analytical Chemistry, 1(2), 12-20.

[13] Dibofori-Orji, A. N. and Edori, O. S. (2015). Analysis of some heavy metals $(\mathrm{Pb}, \mathrm{Cd}, \mathrm{Cr}, \mathrm{Fe}, \mathrm{Zn})$ in processed cassava flour (garri) sold along the road side of a busy highway. Archives of Applied Science Research, 7 (2), 15-19.
[14] Kassa, B. and Hailay, K. (2014). Spectroscopic determination of trace metals $(\mathrm{Mn}, \mathrm{Cu}$ and $\mathrm{Ni}$ ) content in Moringa oleifera. International Journal of chemical and Natural Sciences, 2 (5), 141-144.

[15] Chauhan, A., Mittu, B. and Chauhan, P. (2015). Analytical method development and validation: A concise review. Journal of Analytical and Bioanalytical Techniques, 6 (1), 1-5.

[16] Iqbal, J., Carney, W. A., LaCaze, S. and Theegala, C. S. (2010). Metals determination in biodiesel (B100) by ICP-OES with microwave assisted acid digestion. The Open Analytical Chemistry Journal, 4, 18-26.

[17] Kiflom, G. and Tarekegn, B. (2015). Determination of some selected heavy metals in fish and water samples from Hawassa and Ziway Lakes. Science Journal of Analytical Chemistry, $3(1), 10-16$.

[18] Shrivastava, A. and Gupta, V. B. (2011). Methods for the determination of limit of detection and limit of quantitation of the analytical methods: Review Article. Chronicles of Young Scientists, 2 (1), 21-25.

[19] Thomas A. L. (2015). Method validation essentials, limit of blank, limit of detection, and limit of quantitation. Bio Pharma International, 28 (4), 48-51.

[20] Mitra, S. (2003). Sample preparation techniques in analytical chemistry (Vol. 162, pp. 6-244). Hoboken: John Wiley and sons, Inc.

[21] Harvey, D. (2000). Modern analytical chemistry (1st ed., pp. 706-7110). Depauw University, United States of America: McGraw-Hill.

[22] USEPA. (2010). National functional guidelines for inorganic superfund; Data review.USEPA-540-R10-011, Washington, DC.

[23] FAO/WHO (Codex Alimentarius Commission). (2001). Food additives and contaminants. Joint FAO/WHO food standards program: ALINORM 01/12A: 1-289.

[24] WHO. (1998). Quality control methods for medicinal plant materials, WHO, Geneva, Switzerland.

[25] Umar, M. A.and Salihu, Z. O. (2014). Heavy metals content of some spices available within FCT-Abuja, Nigeria. International Journal of Agricultural and Food Science, 4 (1), 66-74. 